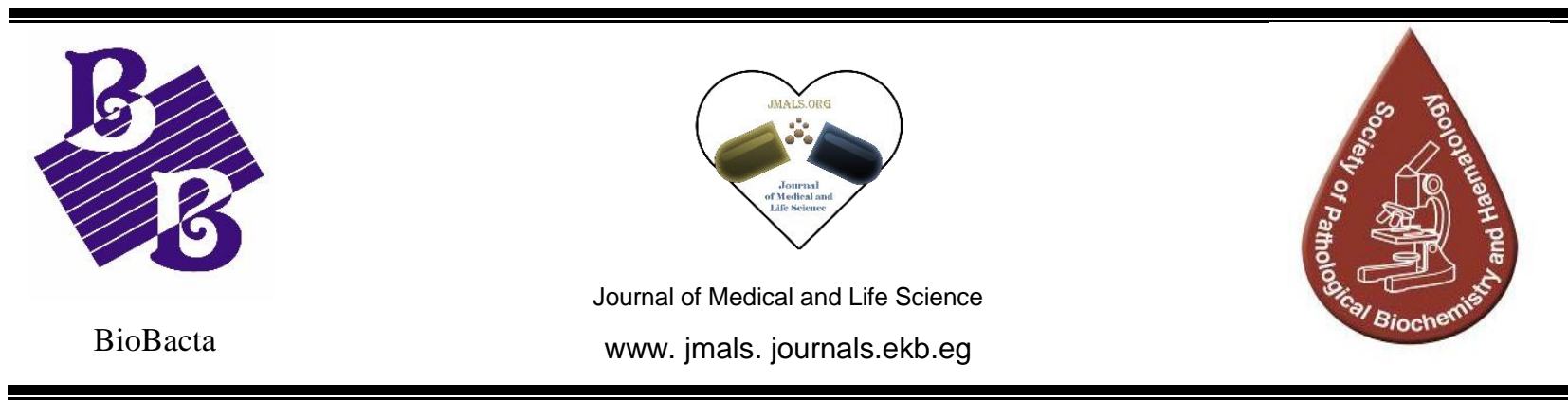

\title{
Effect of Acacia arabica gum on histochemical changes in the renal cortex of rats exposed to gamma radiation
}

\section{Heba Ahmed Mohamed Kandeal ${ }^{1}$, Hemmat Mansour Abdelhafez ${ }^{1}$, Fatma Ahmed Eid, ${ }^{1}$ and Amr Mahmoud Abd Elhady ${ }^{2}$}

\author{
${ }^{1}$ Zoology Department, Faculty of Science, AL-Azhar University, Egypt \\ ${ }^{2}$ Misr University for Science and Technology, Egypt
}

DOI: $10.21608 / j m a l s .2021 .142591$

\section{ABSTRACT}

Objective: Lately, gum Arabic (GA) is traditionally used in Middle East countries to ameliorate renal function of patients with chronic renal failure (CRF). This action is controversial and it is still experimentally under evaluation. We aimed to shed more light on the potential effects of GA against $\gamma$-rays-induced nephrotoxicity in irradiated rats. Forty-eight male albino Sprague-Dawley rats were divided into four groups: control group(C), irradiated groups (R) $5 \mathrm{~Gy}$, gum Arabic groups (GA) $25 \mathrm{mg} / \mathrm{kg}$ orally administrated for 3 weeks, and GA+R groups, rats were treated orally with $25 \mathrm{mg} / \mathrm{kg}$ GA for one week before and three weeks after irradiation $(\mathbf{G A}+\mathbf{R})$. The experimental rats were sacrificed after 7 and 21 days of irradiation. Histochemical examination of kidney cortex tissue of R groups showed significantly decreased PAS-positive materials, total protein content, and total DNA content, but it significantly increased amyloid $\beta$-protein content relative to the control group. While treatment with GA before and after irradiation showed a nonsignificant change in PAS-positive materials and the content of total protein, total DNA, and amyloid $\beta$ protein throughout the examined kidney cortex. According to the results obtained in the current study using GA as a natural agent showed a strong cytoprotective effect against the histochemical changes due to its radioprotective effect.

Keywords: Gum Arabic, Radiation, Histochemistry, Kidney, Rats.

\section{Introduction}

Radiation is usually defined as the emission and propagation of energy in the form of waves or particles through space or matter (Paroli and Potenza, 2017). The effects of ionizing radiation on biological systems were mainly generated from experimental studies on animals and radiation accidents. These effects depend on many factors such as radiation type, radiation dose, and radiosensitivity of the tissue receiving the radiation, and also the volume of tissue exposed (El-Naggar, 2009). The ionizing radiation effects, either by cell death or by indirect action through ionization of water, generates relative oxygen species (ROS). ROS causes the oxidation of proteins, DNA, and lipids (Gaschler \& Stockwell, 2017). Gamma rays are ionizing radiation 
and thus are biologically hazardous (Grupen $\boldsymbol{e t}$ al., 2005). Exposure to ionizing radiation increases the production of reactive oxygen species (ROS) such as superoxide $\left(\mathrm{O}_{2}^{-}\right)$, hydroxyl radical $\left(\mathrm{OH}^{\cdot}\right)$ and hydrogen peroxide $\left(\mathrm{H}_{2} \mathrm{O}_{2}\right)$ and cause lipid peroxidation in cell membrane and damage to cellular activities leading to physiological disorders and dysfunction of cells and tissues (Sarhan, 2020). The proposed mechanisms of injury from free radicals include direct attack, lipid peroxidation, DNA modification, and enzyme degradation /inactivation (Mahgoup et al., 2020). Clear histochemical changes were observed after whole-body gamma irradiation in the kidney tissue of rats (Abdelhafez et al., 2017). Gum Arabic is defined as an edible, water-soluble dietary fibrous heteropolysaccharide, made from the dried gummy exudate obtained and cultivated as a cash crop in agroforestry systems from the stems and branches of Acacia senegal or Acacia seyal trees (Said et al., 2019). GA is rich in $\mathrm{Ca}^{2+}, \mathrm{Mg}^{2+}$, and $\mathrm{K}^{+}$, widely used in the pharmaceutical, cosmetic, and food industries as an emulsifier and stabilizer (Ali et al., 2013). Experimentally, gum Arabic has been used in the Middle East and North Africa countries in the traditional treatment of a variety of diseases, such as renal failure, hepatic, cardiac, anemia, and diabetes mellitus, also used as an oral hygienic substance, antidiarrheal and anti-inflammatory for intestinal mucosa and inflamed skin, it improves the patients' digestive systems and improves appetite and for kidney disease patients (El-shama, 2018; Said et al., 2019). In mice and rats, GA has been reported to act as a protecting agent against hepatic and renal toxicities (Nemmar et al., 2019). The protective effects of GA are likely to be related to its antioxidant and anti-inflammatory and cytoprotective properties (Hammad et $\boldsymbol{a l}$., 2019). It is a widely known safe dietary fiber that has an impact on bacterial mass and enzyme activity; the cecum's bacteria count may rise due to more dietary fiber content without altering the sorts of bacteria. The relative amounts of acetate and butyrate produced depend on the amount of GA fed (Jaafar, 2019).

\section{Materials and Methods}

\subsection{Radiation facility}

A Canadian gamma cell-40, Cesium-137 source, located at the National Center for Radiation Research and Technology (NCRRT), Cairo, Egypt, was used to conduct whole-body $\gamma$-irradiation of rats. At the time of the experiment, the dose rate was $0.6 \mathrm{~Gy} / \mathrm{min}$. Rats were exposed for $10 \mathrm{~min}$ to reach a single dose of 5 Gy.

\section{2 . Gum Arabic (GA)}

Gum Arabic is a soluble dietary fibre obtained naturally from the stems and branches of Acacia arabica trees (Family: Leguminosae). GA powder was purchased from El-Gomhouria company (Cairo, Egypt), freshly suspended in distilled water, and administered orally to the rats at a dose of $25 \mathrm{mg} / \mathrm{kg} /$ day using a gastric tube for consecutive 21 days according to the method of Gamal El-din et al. (2003).

\subsection{Experimental animals}

Forty-eight male Albino Sprague-Dawley rats were used in this study.

weighing 160-180 grams were purchased from the Egyptian Holding Company for Biological Products and Vaccines, Helwan, Cairo, Egypt. The animals were kept in the laboratory for 2 weeks before the experimental work for acclimatization and they were housed in specially designed cages, 6 rats per cage, with controlled air, temperature, and relative humidity. The animals were fed standard rodent pellets. Food and water were made available adlibitum throughout the whole experimental period.

\subsection{Experimental design}

Male Albino rats were randomly divided into four groups (12 rats in each group)

Group 1: Control (C)

Group 2: Whole body $\gamma$-irradiated (5Gy) animals (R).

Group 3: gum Arabic ( $25 \mathrm{mg} / \mathrm{kg}$ body weight) daily oral administrated by gavage for 3 weeks (GA).

Group 4: GA-irradiated group rats were treated orally with $25 \mathrm{mg} / \mathrm{kg}$ body weight/day of GA for one week before and three weeks after irradiation $(\mathbf{G A}+\mathbf{R})$. 
The experimental rats were sacrificed on days 7 and 21 post-irradiation.

\subsection{Histochemical techniques}

After 7 and 21 days, the control and all treated groups were sacrificed, and then the kidneys were quickly removed and fixed for 24 hours in 10 percent neutral formalin followed by dehydration in ascending grades of alcohol, clearing in xylene, and embedding in paraffin wax. The sections were then cut at a thickness of $5 \mu$ using a microtome (SLEE MAINZ-Cut 4050Microtome-Lise-Meitner-Str-155129-Germany) and stained with Periodic acid Schiff's technique for detection of PAS-positive materials (Drury and Wallington, 1980), mercuric bromophenol blue method for detection of total protein (Mazia et al., 1953), Feulgen reaction for detection of DNA (Drury and Wallington, 1980) and Congo red technique for detection of amyloid protein (Valle, 1986).

\section{6-Quantitative histochemical analysis}

The optical density of histochemically PAS, mercuric bromophenol blue, Feulgen, and Congo red-stained sections of a kidney of the control and treated groups was recorded using IPWIN 32 image analysis software. The mean optical density was used to compare the PAS-positive content, total protein content, total DNA content, and amyloid $\beta$-protein content of the different groups. The comparison was established as the mean of the treated group value with the control group.

\section{7-Statistical analysis}

Statistical analyses were performed by using analyses of variance (ANOVA) according to the method of Snedecor and Cochran (1980). The data were processed and analyzed using the SPSS software (Statistical Analysis for Social Science, Version 8). Significant differences between treatment means were determined by student t-test. Data presented as mean $\pm \mathrm{SE}$ and $\mathrm{P} \leq 0.05$ were considered statistically significant.

\section{8-Laboratory facilities}

Facilities including animal housing, histochemical and quantitative image analyses had been made available by the Zoology Department, Faculty of Science, Al-Azhar University (Girl's Branch).

\section{Results}

\section{PAS-positive materials}

Light microscopic examination of the kidney cortical section of the control rats showed normal distribution of polysaccharides where a strong positive reaction was seen in the glomeruli, Bowman's capsules, renal tubules, brush borders of the proximal convoluted tubules, and the basement membranes of the glomerular capillaries (Fig. 1). Exposure of rats to $5 \mathrm{~Gy}$ of gamma radiation showed an obvious decrease in the PAS +ve materials in both proximal and distal convoluted tubules with an intense reaction in the congested glomeruli, the brush borders of the proximal convoluted tubules, and the basement membranes of the convoluted tubules after 7 (Fig. 2) and 21 days (Fig. 3) of $\gamma$-radiation exposure. A significant decrease in the mean value which reached 0.363 and 0.372 after 7 (Fig. 2) and 21 days (Fig. 3) of $\gamma$-irradiation respectively was also depicted as compared to the control value 0.442 (table 1). Administration of gum Arabic (GA) only for 7 and 21 days respectively to normal rats showed a non-significant change in the mean value witch reached $0.422 \& 0.497$ in the kidney cortical sections after 7 (Fig. 4) and 21 days (Fig. 5) of treatment respectively (table 1). Sections of rats exposed to gamma radiation following gum Arabic administration showed more or less normal appearance of the PAS +ve materials throughout the examined kidney cortex with a nonsignificant decrease in the mean value which reached 0.409 and 0.415 after 7 (Fig. 6) and 21 days (Fig. 7) of $\gamma$-irradiation process respectively (Table $\mathbf{1}$ ). 


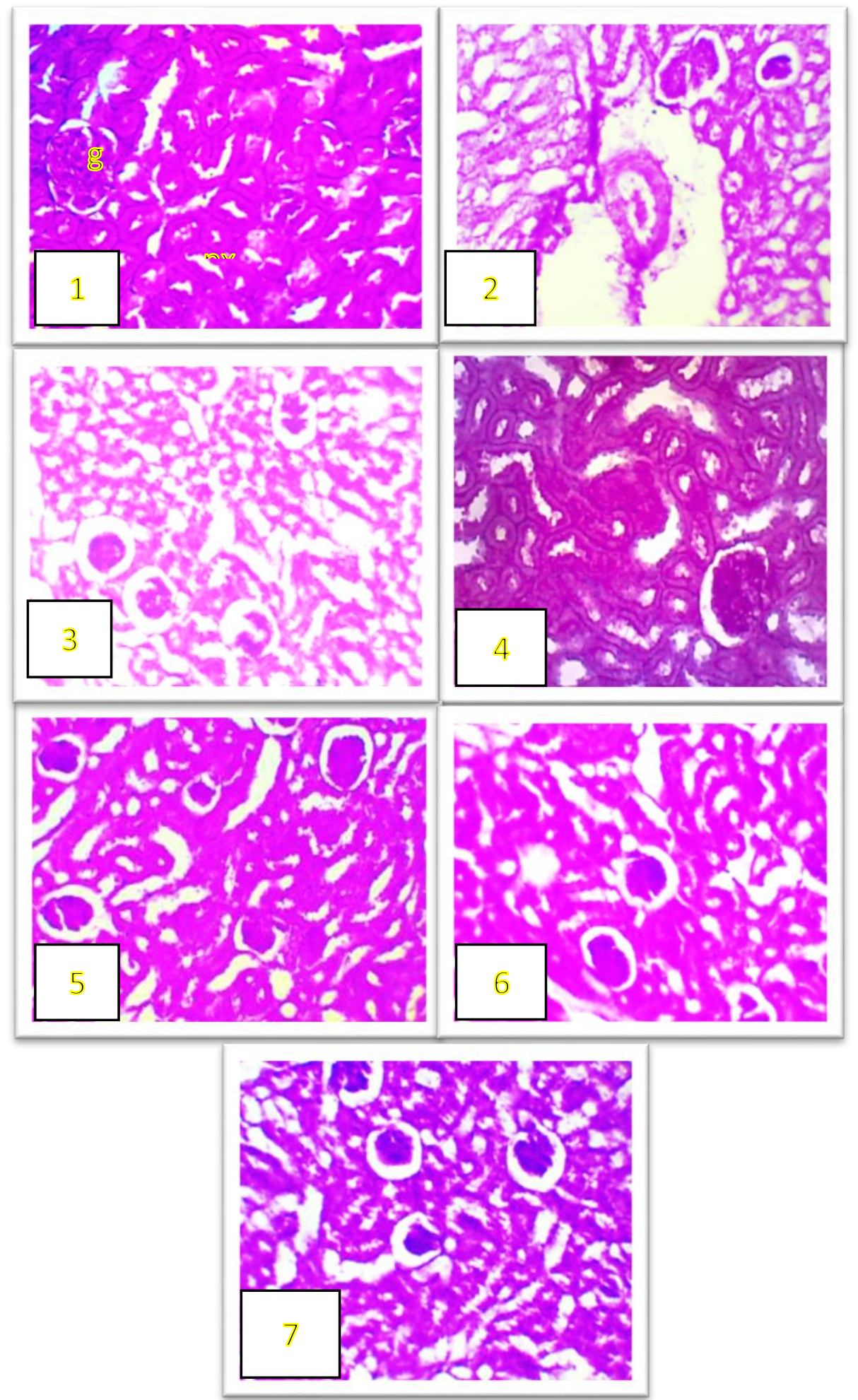

Figs. 1-7- Photomicrographs in the kidney cortical sections of the control and treated groups showing the distribution of PAS +ve materials. (PAS stain X 200) Fig. 1- The control group showing densely stained PAS + materials in the glomeruli (g), basement membranes, convoluted tubules, and brush borders of the proximal tubules (px). Figs. 2\&3- Showing a decrease in the PAS +ve materials in the glomeruli and some epithelial cells of the convoluted tubules after 7 (Fig. 2) and 21 days (Fig. 3) of exposure to gamma radiation. Figs. 4\&5- Showing moderately stained PAS +ve materials in sections of the kidney cortical tissue of GA groups after 7 (Fig. 4) and 21 days (Fig. 5) of treatment respectively. Figs. 6\&7- Showing somewhat normal appearance of PAS +ve materials in sections of the kidney cortex of GA+R groups after 7 (Fig. 6) or 21 days (Fig. 158) following $\gamma$-radiation exposure. 


\begin{tabular}{||l|c|c|c|c||}
\hline \multirow{2}{*}{ Parameter } & \multicolumn{4}{|c||}{ PAS-positive materials } \\
\hline \multirow{2}{*}{ Troups } & \multicolumn{2}{|c|}{ Seven days } & \multicolumn{2}{c||}{ Twenty-one days } \\
\cline { 2 - 5 } & $\begin{array}{c}\text { Mean } \\
\pm \text { S.D }\end{array}$ & $\begin{array}{c}\text { \% } \\
\text { Change }\end{array}$ & $\begin{array}{c}\text { Mean } \\
\pm \text { S.D }\end{array}$ & $\begin{array}{c}\% \\
\text { Change }\end{array}$ \\
\hline \hline \multirow{2}{*}{ Control } & $0.442 \pm 0.145$ & $0.0 \%$ & $0.442 \pm 0.145$ & $0.0 \%$ \\
\hline \multirow{2}{*}{ Radiation } & $0.363 \pm 0.021^{*}$ & $-17.87 \%$ & $0.372 \pm 0.052 *$ & $-15.84 \%$ \\
\hline \multirow{2}{*}{ Gum Arabic (GA) } & $0.422 \pm 0.061$ & $-4.52 \%$ & $0.497 \pm 0.03$ & $12.44 \%$ \\
\hline GA + R & $0.409 \pm 0.018$ & $-7.47 \%$ & $0.415 \pm 0.062$ & $-6.11 \%$ \\
\hline
\end{tabular}

Table 1-Showing PAS-positive materials in kidney cortex tissue of the control and all the treated groups of adult male Albino rats-Each value represents the mean \pm standard deviation (SD)-* Significant difference from the control at $\mathrm{P} \leq 0.05$

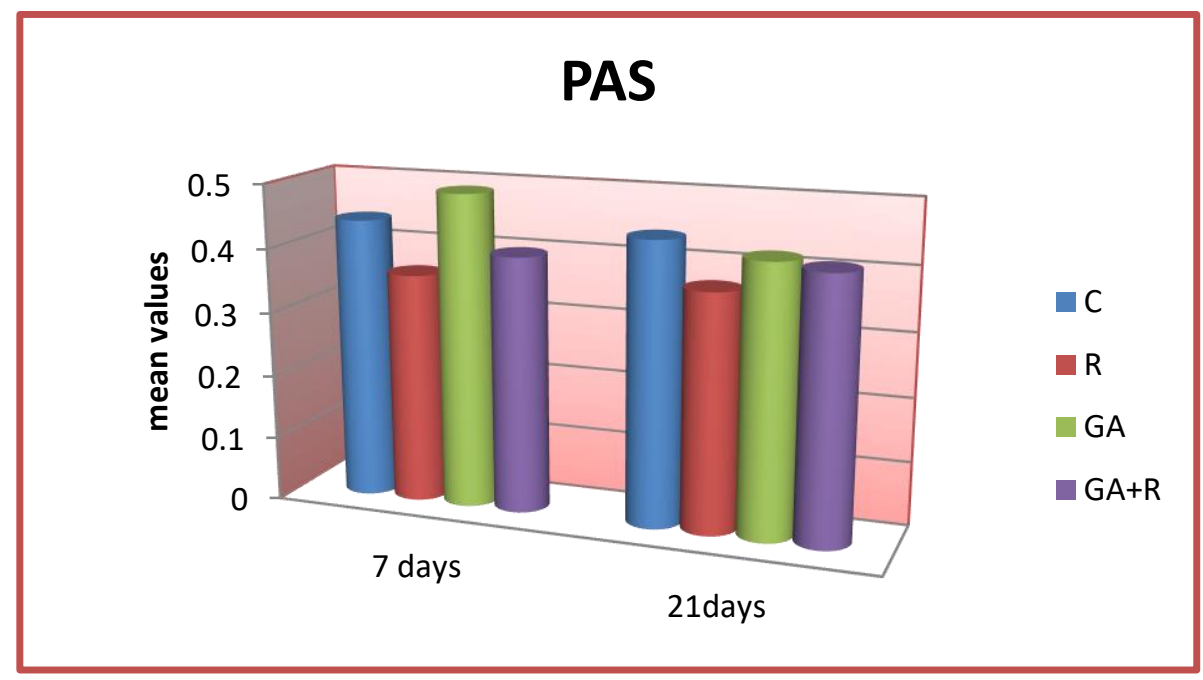

Fig. 8- Showing the mean values of PAS-positive materials relative to the control value.

\section{Total proteins}

Total protein content was demonstrated in a section of the kidney cortex of the control group as a homogenous moderately blue-stained throughout both nuclei and cytoplasm of cuboidal cells of the proximal, distal convoluted tubules and glomerulus. Moderately stained proteinic materials were realized in the brush border of the PCT (Fig. 9). Exposure of rats to 5 Gy of gamma radiation showed a marked decrease in total protein content with a significant decrease in the mean value of total protein which reached $0.289 \& 0.323$ after 7 (Fig. 10) and 21 days (Fig. 11) of gamma irradiation respectively as compared to the control value which reached 0.547 (Table 2). Oral administration of GA only to normal rats showed a nearly normal distribution of the total protein content with a non-significant decrease in the mean value of total protein content which reached $0.451 \& 0.489$ after 7 (Fig. 12) and 21 days (Fig. 13) following gum Arabic administration respectively. Treatment of experimental animals with GA before and after exposure to a single dose 5 Gy of $\gamma$ radiation showed a non-significant decrease in the mean value of the total protein which reached 0.42 $\& 0.43$ after 7 (Fig. 14) and 21 days(Fig. 15) of $\gamma$-radiation exposure process respectively. 

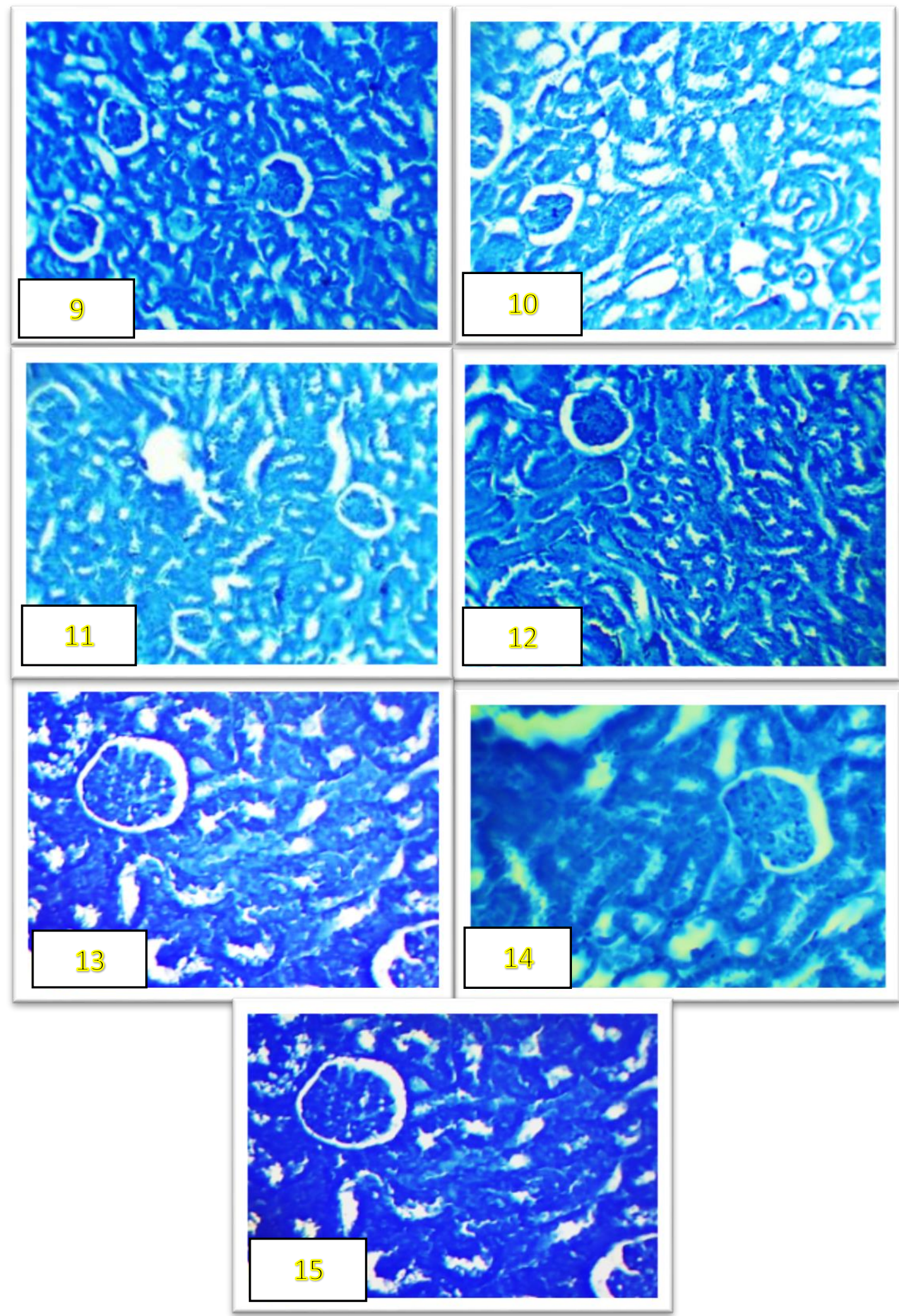

Figs. 9-15- Photomicrographs of the kidney cortical sections of rats of the control and treated groups showing the distribution of the total protein. (Bromophenol blue X 250)

Fig. 9- Showing moderately stained total protein in the glomerular capillaries and convoluted tubules of rats of the control group. Figs. 10\&11- Showing weak staining affinity of total protein in sections of the kidney cortex of rats which were exposed to $\gamma$ - radiation especially in the lobulated glomeruli, but some epithelial cells of the convoluted tubules acquired densely staining affinity after 7 (Fig. 10) and 21 days (Fig. 11) of $\gamma$ - irradiation respectively. Figs. 12\&13- Showing moderately stained total protein in the glomeruli and convoluted tubules of kidney cortex of rats of groups GA after 7 (Fig. 12) and 21 days (Fig. 13) of treatment respectively. Figs. 14\&15Showing somewhat normal appearance of total protein in sections of the kidney cortex of GA+R groups after 7 (Fig. 14) or 21 days (Fig. 15) of $\gamma$ - irradiation.

Received November 5, 2020; Accepted January 19, 2020; Published January 23, 2021 


\begin{tabular}{|c|c|c|c|c|}
\hline Parameter & \multicolumn{4}{|c|}{ Total protein content } \\
\hline Time & \multicolumn{2}{|c|}{ Seven days } & \multicolumn{2}{|c|}{ Twenty one days } \\
\hline Groups & $\begin{array}{l}\text { Mean } \\
\pm \text { S.D } \\
\end{array}$ & $\begin{array}{c}\% \\
\text { Change } \\
\end{array}$ & $\begin{array}{l}\text { Mean } \\
\pm \text { S.D } \\
\end{array}$ & $\begin{array}{c}\% \\
\text { Change } \\
\end{array}$ \\
\hline Control & $0.547 \pm 0.111$ & $0.0 \%$ & $0.547 \pm 0.111$ & $0.0 \%$ \\
\hline Radiation & $0.289 \pm 0.002 *$ & $-47.17 \%$ & $0.323 \pm 0.041 *$ & $-40.95 \%$ \\
\hline Gum Arabic (GA) & $0.451 \pm 0.021$ & $-17.55 \%$ & $0.489 \pm 0.064$ & $-10.6 \%$ \\
\hline $\mathrm{GA}+\mathrm{R}$ & $0.421 \pm 0.028$ & $-23.03 \%$ & $0.435 \pm 0.023$ & $-20.48 \%$ \\
\hline
\end{tabular}

Table 2-Showing total protein content in kidney cortex of the control and all the treated groups of adult male Albino rats -Each value represents the mean \pm standard deviation $(\mathrm{SD})$-* Significant difference from the control at $\mathrm{P} \leq 0.05$

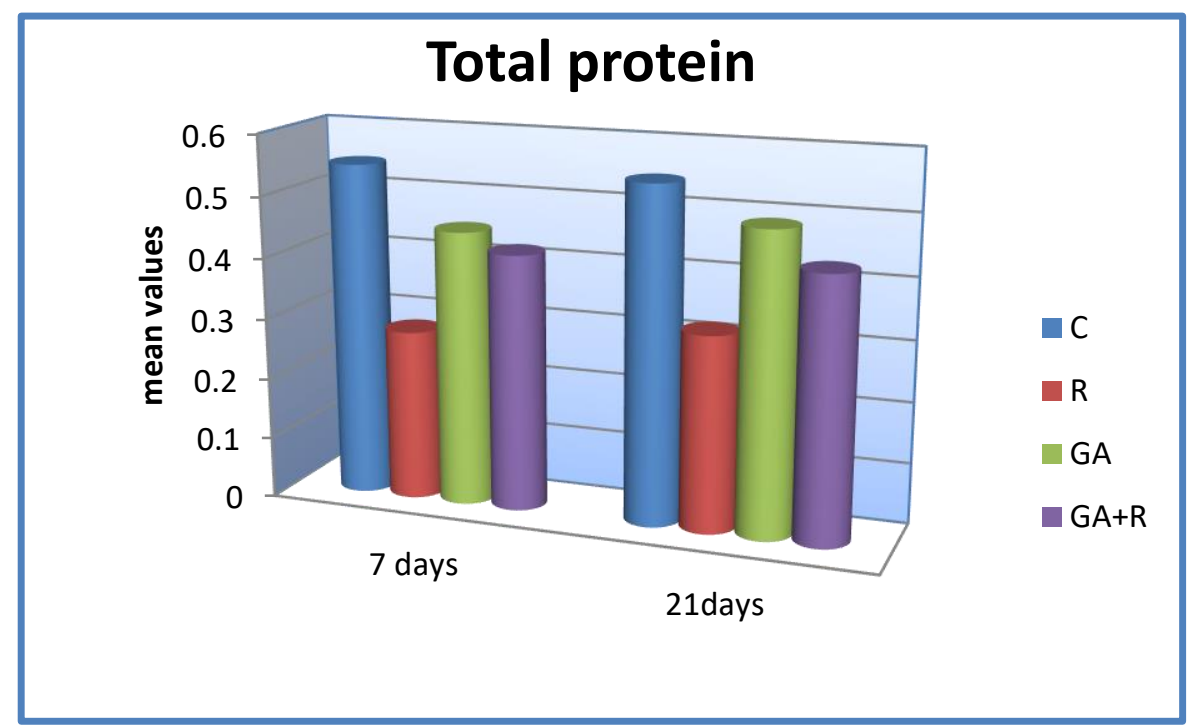

Fig. 16-Showing mean values of total protein content relative to the control value

\section{Total DNA content}

Moderately stained DNA content was detected in nuclei of the glomeruli, proximal and distal convoluted tubules of the kidney cortex tissue of a control rat (Fig. 17). Exposure of rats to $5 \mathrm{~Gy}$ of gamma radiation showed a reduction in the DNA content indicated by faint staining affinity in the proximal and distal convoluted tubules, cellular infiltration area exhibited densely staining affinity with a significant decrease in the mean value of DNA content which recorded 0.321 and 0.328 after 7 (Fig. 18) and 21 days (Fig. 19) of $\gamma$ - irradiation as compared to the control value which reached 0.375 ( Table 3). Gum Arabic administration only showed moderately stained DNA materials with a non-significant decrease in the mean value which reached 0.361 and 0.364 after 7 (Fig. 20) and 21 days (Fig. 21) of oral administration respectively. Rats exposed to a single dose of gamma radiation and treated with GA showed a sign of improvement indicated by moderately stained DNA which exhibited a non-significant decrease in the mean value of DNA content which reached 0.354 and 0.357 after 7 (Fig. 22) and 21 days (Fig. 23) of $\gamma$ radiation exposure respectively. 


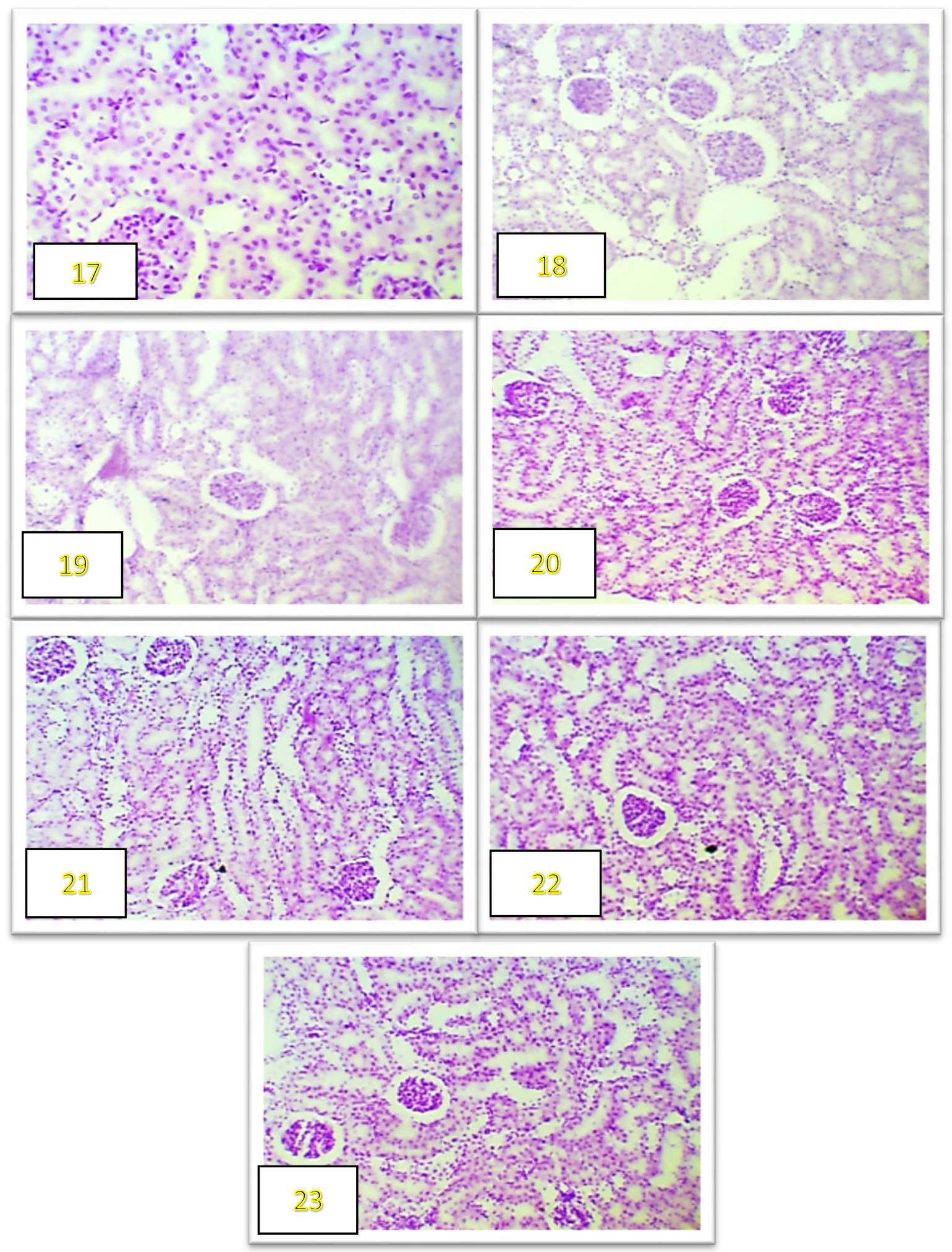

Figs. 17-23- Photomicrographs in the kidney cortical sections of rats of the control and treated groups showing DNA content.

Fig. 17- The control group showing moderately stained DNA in nuclei of the glomerulus, Bowman's capsules, and convoluted tubules indicated by magenta color. (Feulgen stain X 400). Figs. 18\&19- Showing highly reduced staining affinity of nuclei of cells of the convoluted tubules and glomeruli in sections of the kidney cortex of R groups after 7(Fig. 18) and 21 days (Fig. 19) of $\gamma$ - irradiation. (Feulgen stain X 250). Figs. 20\&21- Showing moderately stained DNA distributed throughout the nucleoplasm of the glomerular capillaries and convoluted tubules of rats of groups GA in both groups after 7 (Fig. 20) and 21 days (Fig. 21) of treatment. (Feulgen stain X 250). Figs. 22\&23- Showing somewhat normal appearance of DNA content in the kidney cortex of rats of groups GA+R in both groups after 7 (Fig. 22) and 21 days (Fig. 23) of $\gamma$-irradiation. (Feulgen stain X 250). 


\begin{tabular}{|l|c|c|c|c|}
\hline \multicolumn{1}{|c|}{ Parameter } & \multicolumn{4}{|c|}{ Total DNA } \\
\hline \multirow{2}{*}{ Time } \\
\cline { 2 - 5 } & \multicolumn{2}{|c|}{ Seven days } & \multicolumn{2}{c|}{ Twenty-one days } \\
\cline { 2 - 5 } & $\begin{array}{c}\text { Mean } \\
\pm \text { S.D }\end{array}$ & $\begin{array}{c}\text { \% } \\
\text { Change }\end{array}$ & $\begin{array}{c}\text { Mean } \\
\pm \text { S.D }\end{array}$ & $\begin{array}{c}\text { \% } \\
\text { Change }\end{array}$ \\
\hline Control & $0.375 \pm 0.0001$ & $0.0 \%$ & $0.375 \pm 0.0001$ & $0.0 \%$ \\
\hline Radiation & $0.321 \pm 0.006 *$ & $-14.4 \%$ & $0.328 \pm 0.008 *$ & $-12.53 \%$ \\
\hline $\begin{array}{l}\text { Gum Arabic } \\
\text { (GA) }\end{array}$ & $0.361 \pm 0.0002$ & $-3.73 \%$ & $0.364 \pm 0.0002$ & $-2.93 \%$ \\
\hline GA + R & $0.354 \pm 0.001$ & $-5.6 \%$ & $0.357 \pm 0.0003$ & $-4.8 \%$ \\
\hline
\end{tabular}

Table 3-Showing total DNA content in the kidney cortex of the control and all the treated groups of adult male Albino rats-Each value represents the mean \pm standard deviation (SD)-* Significant difference from the control at $\mathrm{P} \leq 0.05$

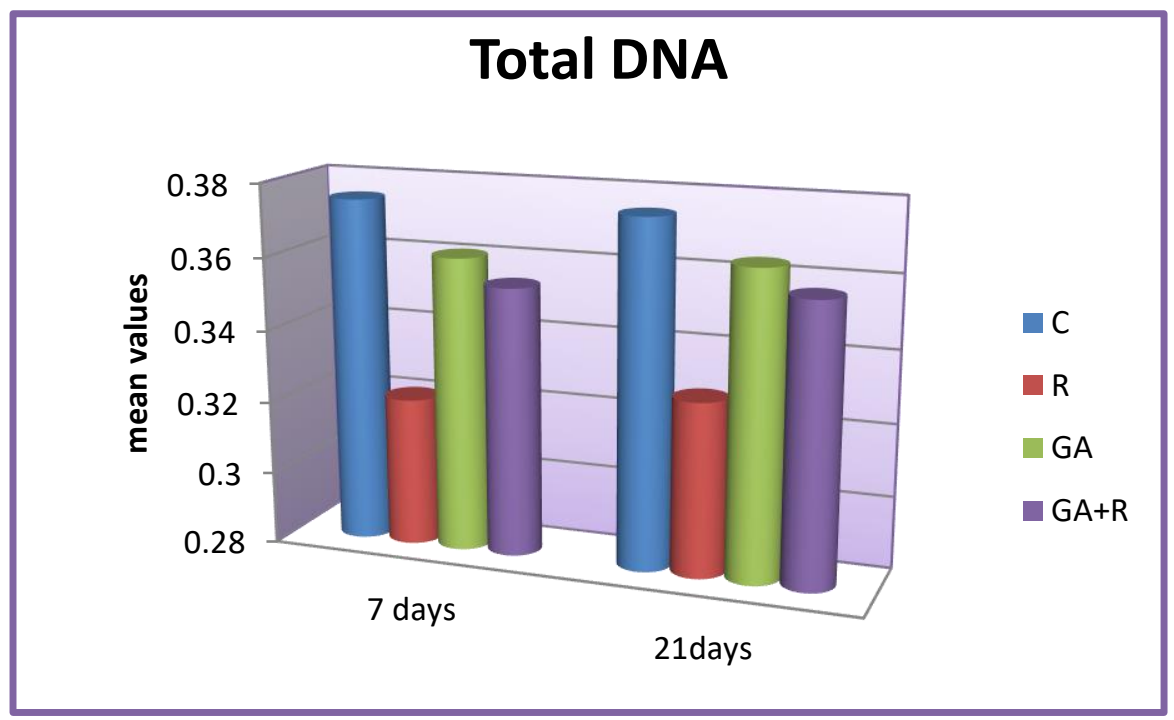

Fig. 24-Showing the mean values of total DNA content relative to the control value.

\section{Amyloid B - protein content}

Faintly stained amyloid $\beta$ - protein was demonstrated in the kidney cortex of the control rats (Fig.25) while, rats exposed to a single dose 5 Gy of gamma radiation showed an intense staining affinity in the proximal and distal convoluted tubules with a significant increase in the mean value which reached 1.36 and 1.231 after 7 (Fig. 26) and 21 days (Fig. 27) of $\gamma$-radiation exposure respectively as compared to the control rats value which reached 0.437 (Table 4). Treatment with GA alone showed a weak staining affinity throughout the kidney cortex with a non-significant change in the mean value of the amyloid $\beta$-protein which reached $0.415 \& 0.439$ after 7 (Fig. 28) and 21 days (Fig. 29) of treatment respectively. Experimental animals which administrated GA and exposed to $\gamma$-radiation exhibited weak staining affinity of $\beta$-amyloid protein and represented a non-significant increase in the mean value of the amyloid $\beta$ - protein content which reached 0.575 and 0.542 after 7 (Fig. 30) and 21 days (Fig. 31) of $\gamma$-radiation exposure. 

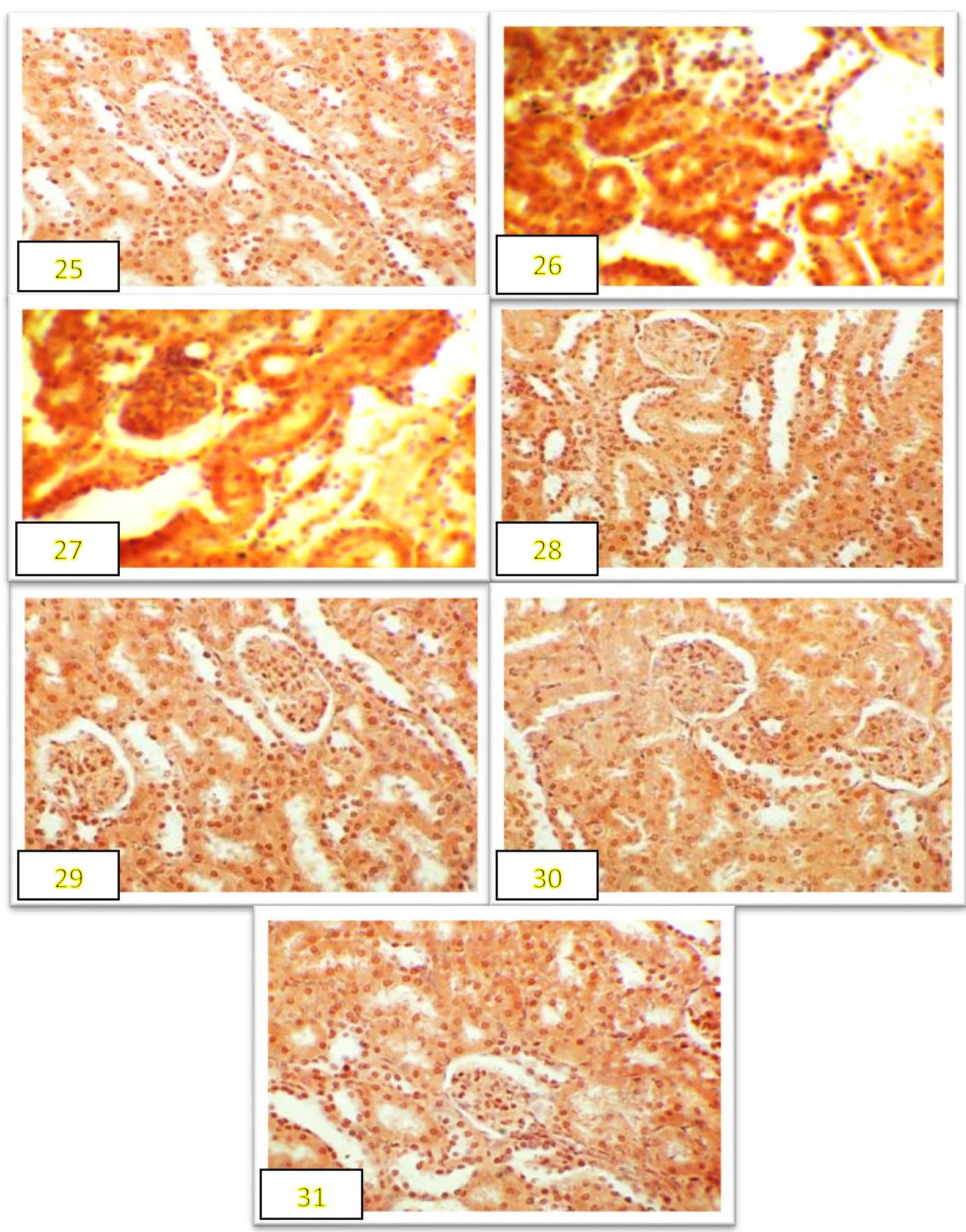

Figs. 25-31- Photomicrographs in the kidney cortical sections of rats of the control and treated groups showing the distribution of amyloid $\beta$-protein content. (Congo red stain X 400).

Fig. 25- Showing faintly stained amyloid- $\beta$ protein in sections of the kidney cortex of the control rats. Figs. 26\&27Showing highly increased amyloid- $\beta$ protein in the glomerular capillaries and basement membranes of some convoluted tubules of R groups after 7 (Fig.26) and 21 days (Fig.27) of $\gamma$-radiation exposure. Figs. 28\&29- Showing normal distribution of amyloid - $\beta$ protein in sections of the kidney cortex of GA groups after 7 (Fig.28) and 21 days (Fig. 29) of treatment. Figs. 30\&31- Showing somewhat normal distribution of amyloid- $\beta$ protein in sections of the kidney cortex of GA+R groups after 7 (Fig.30) and 21 days (Fig.31) of $\gamma$-radiation exposure. 


\begin{tabular}{|c|c|c|c|c|}
\hline \multirow{3}{*}{ 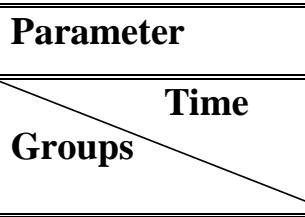 } & \multicolumn{4}{|c|}{ Amyloid content } \\
\hline & \multicolumn{2}{|c|}{ Seven days } & \multicolumn{2}{|c|}{ Twenty-one days } \\
\hline & $\begin{array}{l}\text { Mean } \\
\pm \text { S.D } \\
\end{array}$ & $\begin{array}{l}\text { \% } \\
\text { Change }\end{array}$ & $\begin{array}{l}\text { Mean } \\
\pm \text { S.D } \\
\end{array}$ & $\begin{array}{l}\text { \% } \\
\text { Change }\end{array}$ \\
\hline Control & $0.437 \pm 0.0002$ & $0.0 \%$ & $0.437 \pm 0.0002$ & $0.0 \%$ \\
\hline Radiation & $1.36 \pm 0.007 *$ & $211.21 \%$ & $1.231 \pm 0.052 *$ & $181.69 \%$ \\
\hline Gum Arabic (GA) & $0.415 \pm 0.007$ & $-5.03 \%$ & $0.439 \pm 0.08$ & $0.46 \%$ \\
\hline $\mathrm{GA}+\mathrm{R}$ & $0.575 \pm 0.004$ & $31.58 \%$ & $0.542 \pm 0.04$ & $24.02 \%$ \\
\hline
\end{tabular}

Table 4- Showing amyloid- $\beta$ protein content in kidney cortex of the control and all the treated groups of adult male Albino rats -Each value represents the mean \pm standard deviation $(\mathrm{SD})$-* Significant difference from the control at $\mathrm{P} \leq 0.05$

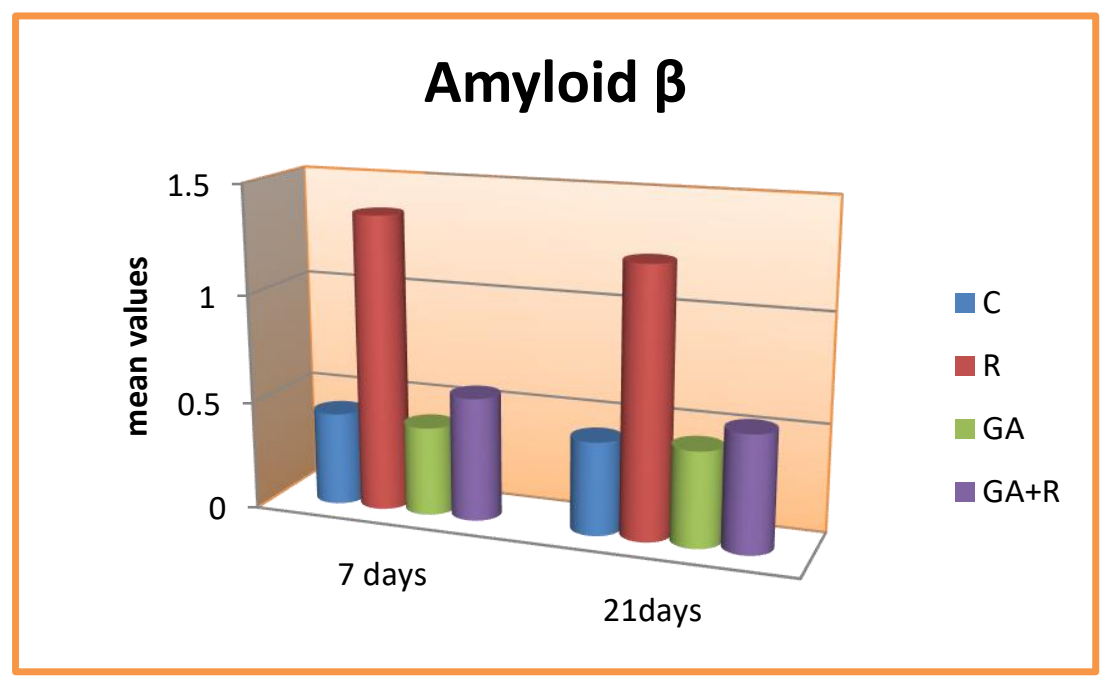

Fig. 32- Showing the mean values of amyloid $\beta$ - protein relative to the control value

\section{4-Discussion}

\section{Polysaccharides}

Concerning the histochemical observations in the current work, sections of the kidney cortex of rats exposed to 5 Gy of $\gamma$-radiation showed a reduction of polysaccharides. According to Zaghloul and Salem (2001) and Koyu et al. (2005), these changes in polysaccharides may be due to failure of Golgi apparatus to synthesize carbohydrate or due to lytic enzymes released from ruptured lysosomes or due to hypoxia. These findings are in agreement with Eid and Al-Dossary (2007) who reported that highly reduced polysaccharides in fetal kidney cortex postirradiation may be due to degeneration and vacuolation observed in most cells of proximal and distal convoluted tubules and renal Malpighian corpuscles or may be due to failure of Golgi apparatus to synthesize polysaccharides.

Reduced staining affinity of PAS +ve materials was detected in kidney tissue of the irradiated rats at dose 2Gy (Emam et al., 2013). Present results showed that male rats that received GA had a normal appearance 
of PAS + ve materials, it is known that GA contains a high percentage of polysaccharides. Yu et al. (2018) investigated the bioactivity of polysaccharides from natural resources, including its diverse pharmacological applications, such as immunoregulatory, anti-tumor, anti-virus, antioxidation, and hypoglycemic activity. The present results were also noticed by El-shama $\boldsymbol{e t}$ al. (2014) who elucidated that male rats that received GA have a normal appearance of PAS +ve materials. Non-significant decrease in the mean value of PAS +ve materials as illustrated in the current investigation in the kidney cortex tissue of the GA+R group after 7 and 21 days of $\gamma$ - irradiation. Similar results were obtained by Tavafi et al. (2012) and Elshama et al. (2014) who found that GA is a nephroprotective agent against acute kidney failure. Helal et al. (2014) noticed that diabetic rats treated with flavonoids showed that the mucopolysaccharide content more or less was similar to the control level. Acacia species is one of the richest resources of bioactive flavonoids, alkaloids, phenolics, saponins, polysaccharides, tannins, and terpenoids (Pal $\boldsymbol{e t}$ al., 2019). Improvement in polysaccharides content observed in this study in group GA+R may be due to the antioxidant activity of gum Arabic (Al-Doaiss and Al-Shehri, 2020).

\section{Total protein}

The present results showed that exposure of rats to 5 Gy of gamma radiation represented a significant decrease in the mean value of total protein in kidney cortex tissue 7 and 21 days following the $\gamma$-irradiation process. This finding was considerably supported by the results of Curran (2000) who reported that radiation-induced a clear inhibition of protein contents in the kidney (cortex and medulla) this may be due to the release of glucocorticoid which breakdown protein in the tissue. In more detail, Kempner (2001) explained that this decrease in protein level may be due to gamma-irradiation which can damage or inactivate proteins by two different mechanisms. First, it can rupture the covalent bonds in the target protein molecules as a direct result of a photon depositing energy into the molecule. Second, it can act indirectly, link with a water molecule, producing free radicals and other non-radical reactive oxygen species that are in turn responsible for most (99.9\%) of the protein damage. Similar findings were obtained by Abdelhafez et al. (2017) who stated that a single dose of total body gamma irradiation (6 Gy) to rats induced a detectable decrease in total protein. This reduction in protein content may be due to the decreased ability of the tissue to produce proteins (Al Gahtani, 2006). Similarly, Ali et al. (2007) revealed that rats exposed to whole-body gamma radiation at $7.5 \mathrm{~Gy}$ showed a decline in total protein compared to the control group. A noticeable decrease in the total proteins was observed in proximal and distal convoluted tubules and glomeruli post-exposure to radiation, but increased stainability was detected in RBCs (Eid and Al-Dossary, 2007). Moreover, Sanaa et al. (2012) reported that tissue total proteins and total lipids, decreased significantly at different sampling times post-radiation exposure(5.7 Gy) at a dose rate of $2.67 \mathrm{rad} / \mathrm{sec}$. Abdel-Meguid $\boldsymbol{e t}$ al. (2012) stated that the decrease in protein could be attributed to the disruption of lysosomal membranes under the effects of various toxicants; thus, led to the liberation of their hydrolytic enzymes in the cytoplasm. Additionally, the presence of hydrolytic enzymes may cause the lysis and dissolution of the target material within the cytoplasm. Decreased total protein in the glomeruli, Malpighian's corpuscles, walls of the convoluted tubules with negatively stained degenerated areas were noticed in the kidney cortex of irradiated (2Gy) pregnant rats (Bakhit, 2013). Irradiation of animals at $900-1800 \mathrm{MHz}$ resulted in a marked reduction in the total protein content giving weak to moderate reactions in some hippocampal areas (Mohammed, 2014). According to Eid et al. (2014), this decrease may be due to the decrease in ribosomal granules of the rough endoplasmic reticulum or due to the decrease in DNA content. Antebi et al. (2016) also concluded that ionizing radiation at high doses $(50 \mathrm{kGy})$ caused significant reduction (between $35 \%$ and $52 \%$ ) in the 
concentrations of total protein. Eid et al. (2018) revealed highly decreased total protein content in the heart tissue of the irradiated group (4Gy) after 5 and 21 days. Reactive oxygen species directly impair mitochondrial function, protein synthesis and structure, DNA synthesis, and cellular repair mechanisms(Perazella and Moeckel, 2010).

Oxidative stress is already found in the early stages of renal disease and increases with declining kidney function (Zhou et al., 2019). In the present study, rats in groups $\mathrm{GA}$ or $\mathrm{GA}+\mathrm{R}$ showed a non-significant decrease in the mean value of total protein compared to the control group in sections of the kidney cortex tissue. The improvement in protein content in GA and $\mathrm{GA}+\mathrm{R}$ may be due to the presence of polysaccharides and flavonoids. The previous studies have indicated that polysaccharides, alkaloids, coumarins, flavonoids, saponins, and other compounds possess anti-radiation effects (Shi et al., 2013; Eid et al., 2018; Boojar, 2020). They declared that the mechanism of this effect may be attributed to protecting DNA, inhibiting immune injury, protecting the hematopoietic system, and scavenging free radical activities of GA.

Gum Arabic has antioxidant action, by testing whether treatment with gum Arabic has any effect on the concentrations of some free radical scavengers [reduced glutathione (GSH), ascorbic acid (AA), lipid peroxidation (LP), and superoxide dismutase (SOD)] in the kidneys and liver of healthy rats given gum Arabic in the drinking water at a concentration of 2.5, 5.0 or $10.0 \%$ for eight consecutive days. The results indicated that the gum Arabic, at the three doses used, did not significantly affect any of the variables measured. It seems highly unlikely that gum Arabic has a palliative effect on renal failure through an antioxidant mechanism (Ali, 2004).

\section{DNA content:}

In the present study exposure of rats to $5 \mathrm{~Gy}$ of gamma radiation illustrated a significant decrease in the mean value of DNA materials. Ionizing radiation exerts adverse biological effects through direct and indirect processes breaks in DNA strands and the production of oxygen free radicals. These oxygen free radicals in turn damage and mutate cellular DNA, leading to an increased rate of malignancy with radiation exposure. In addition, free radicals destroy supporting cellular structures, including organelles and cell membranes, resulting in programmed cell death (Robbins and Zhao, 2004).

Increased mutation and decreased DNA content in nuclei of the cells post-irradiation may be due to the production of active oxygen which leads to oxygen pressure and increased free radicals which affect chains of DNA that lead to cancer (Mahmod, 2006).

Similarly, Purohit et al. (2007) noticed that in the irradiated animals, the values of glycogen, protein, and DNA decreased in kidney tissue continuously up to day 7 and increased thereafter up the day 28. The decrease in both DNA and total protein was attributed to arrested metabolism or to use it to build up new cells or enzymes to reduce the radiation stress and also disruption of lysosomal membranes under the effect of various toxicants leading to liberating their hydrolytic enzymes in the cytoplasm and resulted in marked lysis and dissolution of the target materials (Sakr and Shalaby, 2011). Abdelhafez et al. (2017) illustrated that the decrease of DNA content was associated with a decrease in protein content in kidney cells of the rats exposed to 6Gy of $\gamma$-radiation. Eid $\boldsymbol{e t}$ al. (2018) noticed a decrease in the staining affinity of DNA content in the heart tissue of rats following exposure to 4Gy of $\gamma$-radiation. Zhou et al. (2019) demonstrated that oxidative stress, characterized by the generation of reactive oxygen and nitrogen species, produces permanent genomic alterations and cellular DNA damage. Results of the present study showed a non-significant decrease in total DNA content in the kidney cortex in the groups treated with $\mathrm{GA}$ alone or $\mathrm{GA}+\mathrm{R}$ in comparison with the control. This improvement may be due to the antiinflammatory and antioxidant properties of GA that protects against DNA damage initiated by free radicals (Mohamed et al., 2015). They added that the antioxidative capacity of GA could prevent the 
formation of superoxide completely and the oxidative stress-induced DNA double-strand breaks to a certain extent. DNA double-strand breaks are serious lesions, initiating genomic instability, inducing cell death, or even mutations. A lowered amount of superoxide anions and a lowered incidence of double-strand breaks could in part explain the positive effect of GA on the progression of kidney disease. This positive effect can also be ascribed to the ability of GA to lower the blood pressure in the adenine-treated rats (Ali et al., 2011; Jaafar, 2019), other authors showed an increase of ROS in animals with hypertension (Welch, 2006; Schupp et al., 2011).

\section{Amyloid- $\beta$ protein}

The results of the current study recorded a significant increase in the amyloid- $\beta$ protein content in the kidney cortex tissue, in the glomerular capillaries, especially in the basement membrane of some convoluted tubules, and in the hemorrhagic areas of the irradiated animals throughout the experimental periods.

Amyloid- $\beta$ peptide $(A \beta)$ is still best known as a molecule to cause Alzheimer's disease (AD) through accumulation and deposition within the frontal cortex and hippocampus in the brain. Thus, strategies for developing $\mathrm{AD}$ drugs have been focused on the reduction of $A \beta$ in the brain (Sang-Sun and Sangmee, 2012). Amyloid $\beta$ - is produced by both brain and peripheral cells and can pass through the blood-brain barrier (Davanipour et al., 2007). Mohammed (2014) showed that whole-body microwave exposure of $1 \mathrm{~h} /$ day for 140 days revealed a slight deposition of amyloid $\beta$-protein in the nuclei of hippocampus cells. The application of Congo red stain recorded slightly increased amyloid $\beta$ deposits inside some of the granular cells of the hippocampus of the irradiated mice, but those neurons which underwent apoptosis in most of the hippocampal areas exhibited a high strong amyloid $\beta$ reaction. In the same direction, Eid et al. (2018) showed that exposure of rats to gamma radiation increased amyloid $\beta$-proteins in the heart tissues after 5 or 21 days of $\gamma$ - radiation exposure. In addition,
Abdelhafez et al. (2017) found a significant increase in the amyloid- $\beta$ protein content in the kidney cortex tissue of rats after exposure to $6 \mathrm{~Gy}$ gamma radiation. The present finding showed a weak staining affinity and a non-significant change in the mean value of amyloid $\beta$ - protein $(A \beta)$ content in GA and $G A+R$ groups after 7 and 21 days of treatment in the kidney cortex tissues.

Ono et al. (2006) proved that there are several antioxidant compounds with anti-amyloidogenic effects. Ameliorated results in different organs of the irradiated rats treated with GA observed in this study may be due to antioxidant and anti-inflammatory effects (Ali et al., 2018; Al-Doaiss and Al-Shehri, 2020). The use of antioxidant compounds may also have a role in reducing $A \beta$ amyloid-induce toxicity. These substances include blueberries, flavonoids, polyphenols, resveratrol, epicatechin, and melatonin (Massaad, 2011). Anti-oxidant treatments in the early stages of pathogenesis were able to alleviate the functional impairment (Hsiao et al., 2012) and to reduce brain $\mathrm{A} \beta$ in Alzheimer's disease mouse models (Chu, 2012; Cheng et al., 2014). Grossi et al. (2013) concluded that dietary supplementation of GA may prevent or delay the occurrence of Alzheimer's diseases and may reduce the severity of its symptoms such as amyloid deposition.

\section{5-References}

Abdelhafez, H. M.; Al-Tounsy, M. M. and Omran, D. A. (2017): The possible therapeutic effect of ethanolic olive leaves extract or bone marrow mesenchymal stem cells on the kidney of gamma-irradiated adult male rats. Stem Cell, 8(1):60-81.

Abdel-Meguid, N. E.; Chmaisse, H. and Abouzeinab, N. S. (2012): Silymarin ameliorates Cisplatin induced hepatotoxicity in rats: histopathological and ultrastructural studies. J. Biol. Sci., 13: 463-477.

Al-Doaiss, A.A. and Al-Shehri, A.M. (2020): Protective effect of gum Arabic/insulin 
against histological changes in testes of the diabetic rats. Int. J. Morphol., 38(2): 340347.

Al Gahtani, S. (2006): Histological and histochemical studies on the effect of two different types of magnetic field on the liver and kidney of Albino rats. M.Sc. Thesis, Zoology Department, Girls College of Science, Dammam, K.S.A.

Ali, B.H. (2004): Does gum Arabic have an antioxidant action in rat kidney? Renal Failure, 26(1): 1-3.

Ali, B. H.; Al-Husseni, I.; Beegam, S.; Al-Shukaili, A.; Nemmar, A.; Schierling, S. et al. (2013): Effect of gum Arabic on oxidative stress and inflammation in adenine-induced chronic renal failure in rats. Plos One, 8(2):1-7.

Ali, B. H.; Al Zaabi, M.; Karaca, T.; Al Suleimani, Y.; Al Balushi, K. A.; Manoj, P.; Ashique, M. and Nemmar, A. (2018): Potassium bromate-induced kidney damage in rats and the effect of gum Acacia thereon. .Am. J. Trans. Res., 10(1): 126-137.

\section{Ali, B. H.; Faddah, L.; Rizk, M. and El-Ebiary, H.} (2007): Role of anserine and/or zinc in modulating nucleic acid and protein disorders in rats exposed to gamma irradiation. J. Pharm. Toxic., 2: 1-19.

Ali, B. H.; Ziada, A.; Al Husseni, I.; Beegam, S.; Al-Ruqaishi, B. and Nemmar, A. (2011): Effect of Acacia gum on blood pressure in rats with adenine-induced chronic renal failure. Phytomedicine, 18(13):1176-1180.

Antebi, U.; Mathor, M. B.; Silva, A. F.; Guimaraes, R. P. and Honda, E. K. (2016): Effects of ionizing radiation on proteins in lyophilized or frozen demineralized human bone. Rev. Bras. Orto., 51(2):224-230.
Bakhit, M. A. (2013): The possible protective role of transplanted bone marrow in mitigation of radiation injury in pregnant rats and their fetuses. Ph.D. Thesis, Zoology Department, Faculty of Science, Al-Azhar University.

Boojar, A. M. M. (2020): An overview of the cellular mechanisms of flavonoids radioprotective effects. Adv. Pharm. Bull., 10(1): 13-19.

Cheng, D.; Low, J. K.; Logge, W.; Garner, B. and Karl, T. (2014): Chronic cannabidiol treatment improves social and object recognition in double transgenic APPswe/ PS1E9 mice. Psychopharmacology, 231: 3009-3017.

Chu, Y. F. (2012): Crude caffeine reduces memory impairment and amyloid beta (1-42) levels in an Alzheimer's mouse model. Food Chem., 135: 2095-2102.

Curran, R. C. (2000): Color Atlas of Histology. $4^{\text {th }}$ ed. Harvery Miller Publishers, Oxford University, London, pp: 276-288.

Davanipour, Z.; Tseng, C. C.; Lee, P. J. and Sobel, E. (2007): A case-control study of occupational magnetic field exposure and Alzheimer's disease: results from the California Alzheimer's disease diagnosis and treatment centers. BMC Neurol., 7:1322.

Drury, R. and Wallington, E. (1980): Carleton's Histological Technique. $4^{\text {th }}$ ed. Oxford Univ. Press, New York.

Eid, F. A., and Al-Dossary, A. (2007): Ultrastructural, histological and histochemical studies on the effect of electromagnetic field on the liver of pregnant rats and their fetuses. E. J. Hosp. Med., 28: 273-294.

Eid, F. A.; Eldahshan, A. M. and Hamid, S. M. (2018): The possible radioprotective role of Aphanizomenon flos-aquae (AFA) on 
heart of the adult male albino rats. Egy. J. Hos. Med.,71(7): 3559-3571.

Eid, F. A.; Shoman, H. H.; Abu Elnaga, N. A. and Abed El-Halim, H. (2014): Effect of olive leaf extract on the kidney of pregnant diabetic rats and their fetuses. Inter. J. Adv. Res., 2(11): 740-476.

El-Naggar, A. (2009): Medical radiation biology. Am. J. Hum. Genet., 84:605-616.

El-Shama, S. S.; El-Kenawy, A. E.; Osman, H. H., and Youseef, H. M. (2014): Amelioration of indomethacin systemic toxicity by gum Arabic administration in adult albino rats. Int. J. Med. Plants and Alter. Med., 2(3): 032-046.

Emam, M. M. N.; Ibrahim, M. A., and Mohammed, H. A. (2013): The possible protective role of bone marrow transplantation against alternations induced by gamma radiations on heart of pregnant Albino rats and their fetuses. J. Biol. Life Sci., 4(1):247-272.

Gamal El-din, A. M.; Mostafa, A. M.; AlShabanah, O. A.; Al-Bekairi, A. M. and Nagi, M. N. (2003): Protective effect of Arabic gum against acetaminophen-induced hepatotoxicity in mice. Pharma. Res., 48: 631-635.

Gaschler, M. M. and Stockwell, B. R. (2017): Lipid peroxidation in cell death. Biochemical and Biophysical Research

Communications, 482(3): 419-425.

Grossi, C.; Rigacci, S.; Ambrosini, S.; Ed Dami, T.; Luccarini, I.; Traini, C.; Failli, P.; Berti, A.; Casamenti, F. and Stefani, $M$. (2013): The polyphenol oleuropein aglycone protects TgCRND8 mice against $\mathrm{A} \beta$ plaque pathology. Plos One, 8(8): 71702-71708.

Grupen, C.; Cowan, S. and Stroh, T. (2005): Astroparticle Physics. Springer-Verlag
Berlin and Aheidelberg, Berlin. pp: 109-115. Hammad, F.T.; Al Salam, S.; Nemmar, A.; Ali, M. and Lubbad, L. (2019): The effect of Arabic gum on renal function in reversible unilateral ureteric obstruction. Biomolecules, 9(1):1-25.

Helal, E. G. E.; Abou-Aouf, N.; Khattab, S. M.; Shaibah, H. S.; Abu-Taleb, H. M. and Abu-Amara, T. M. (2014): The effects of Jasonia montana (Neheda) on some biochemical and histological parameters of diabetic Albino rats. Egy. J. Hosp. Med., 57: 513-530.

Hsiao, Y. H.; Kuo, J. R.; Chen, S. H., and Gean, P. W. (2012): Amelioration of social isolation-triggered onset of early Alzheimer's disease-related cognitive deficit by $\mathrm{N}$-acetyl cysteine in a transgenic mouse model. Neurobiol. Dis., 45: 11111120.

Jaafar, S.N. (2019): Clinical effects of gum Arabic (Acacia). Iraqi J. Pharm. Sci., 28(2): 916.

Kempner, E. S. (2001): Effects of high-energy electrons and gamma rays directly on protein molecules.J. Pharm. Sci., 90(10):1637-1646.

Koyu, A.; Cesur, G.; Ozguner, F.; Akdogan, M.; Mollaoglu, H. and Ozen, S. (2005): Effects of $900 \mathrm{MHz}$ electromagnetic field on TSH and thyroid hormones in rats. Toxic. Lett., 157:257-262.

Mahgoub, S.; Sallam, O. A.; Sarhan, A. K. H.; Ammar, A. A. and Sorora,H. S. (2020): Role of Diosmin in protection against the oxidative stress induced damage by gamma-radiation in Wistar Albino rats. Reg. Toxic. Pharma., available on: https://doi.org/10.1016/j.yrtph.2020.10 4622 mahgoub@pharm.helwan.edu.eg 
Mahmod, N. (2006): Electromagnetic fields induced histological changes in mammals. Zoology Department, Faculty of Science, Al-Azhar University Cairo.

Massaad, C. A. (2011): Neuronal and vascular oxidative stress in Alzheimer's disease. Cur. Neuropharmacology, 9: 662-673.

Mazia, D.; Brewer, P.A., and Alfert, M. (1953): The cytochemical staining and measurement of protein with mercuric bromophenol blue. Biol. Bull., 104:5767.

Mohamed, H. A.; Ahmed, N. S.; Hanafi, N.; Zaki, H. F., and Kenawy, S. A. (2015): The renoprotective effect of gum Arabic in gamma-irradiated and cisplatin treated rats. Int. J. Sci. Res., 5(6):1-11.

Mohammed, W. (2014): Histological, histochemical and ultrastructural alterations produced in the brain and eye of newly-born mice exposed to mobile phone microwaves. Ph.D. Thesis, Faculty of Science, Al -Azhar University.

Nemmar, A.; Al-Salam, S.; Beegam, S.; Yuvaraju, P. and Ali, B. H. (2019): Gum Arabic ameliorates impaired coagulation and cardiotoxicity induced by water-pipe smoke exposure in mice. Front. Physiol., 10: 53.

Ono, K.; Yu, R.; Mohri, K. and Ono, S. (2006): Caenorhabditis elegans kettin, a large immunoglobulin-like repeat protein, binds to filamentous actin and provides mechanical stability to the contractile apparatuses in body wall muscle. Mol. Biol. Cell, 17: 27222734.

Pal, K.; Roy, S.; Parida, P. K.; Dutta, A.; Bardhan, S.; Das, S.; Jana, K. and Karmakar, P. (2019): Folic acid conjugated curcumin loaded biopolymeric gum Acacia microsphere for triple negative breast cancer therapy in vitro and in vivo model. Mater. Sci. Biol. Appl.,95(1):204-216.

Paroli, B. and Potenza, M. A. C. (2017): Radiation emission processes and properties: synchrotron, undulator and betatron radiation.Advances in Physics, 2 (3): 9781004.

Perazella, M. A. and Moeckel, G. W. (2010): Nephrotoxicity from chemotherapeutic agents: clinical manifestations, pathobiology and prevention/therapy. Sem. Nep., 30: 570581.

Purohit, R. K.; Chakrawarti, A. and Bhartiya, K. M. (2007): Radiation and cadmium induced biochemical alterations in mouse kidney. Iran. J. Rad. Res., 5 (3): 125-1130.

Robbins, M. E., and Zhao, W. (2004): Chronic oxidative stress and radiation-induced late normal tissue injury. Int. J. Rad. Biol., 80: 251-259.

Said, M. A.; Atwa, S. A. E. and Khalifa, O. A. (2019): Ameliorating effect of gum Arabic and lemongrass on chronic kidney disease induced experimentally in rats. Bull. Nat. Res. Cent., 43(47): 1-8.

Sakr, S. A. and Shalaby, S. Y. (2011): Ginger extract protects metalaxyl-induced histomorphological and histochemical alterations in testes of albino mice. J. Appl. Pharmaceutical Sci., 1 (10): 36-42.

Sanaa, A. A.; Fadda, L. M.; Elebiary, H. and Soliman, M. (2012): Evaluation of the radioprotective action of anserine along with zinc in Albino rats exposed to gamma radiation. J. Appl. Pharm. Sci., 2 (4):115122.

Sang-Sun, Y. and Sangmee, A. J. (2012): Mechanisms of amyloid- $\beta$ peptide clearance: potential therapeutic targets for 
Alzheimer's disease. Biomol. Thera., 20(3): 245-255.

Sarhan, A. K. H. (2020): Protective role of lycopene extracted from tomato (Tomato pomace) against gamma irradiation or carbon tetrachloride-induced brain and liver toxicity in male Albino rats. Egy. J. Hos. Medici., 78 (1): 68-76.

Schupp, N.; Kolkhof, P.; Queisser, N. et al. (2011): Mineralocorticoid receptor-mediated DNA damage in kidneys of DOCA-salt hypertensive rats. FASEB. J., 25: 968-978.

Shi, J.; Cheng, C.; Zhao, H.; Jing, J.; Gong, N. and Lu, W. (2013): In vivo anti-radiation activities of the Ulva pertusa polysaccharides and polysaccharide-iron(III) complex. Int. J. Biol. Macro., 60: 341-346.

Snedecor, W.G. and Cochran, G.W. (1980): Statistical Method. $7^{\text {th }}$ ed. Iowa State University Press, Amesterdam, pp: 66-71.

Tavafi, M.; Ahmadvand, H. and Toolabi, P. (2012): Inhibitory effect of olive leaf extract on gentamicin-induced nephrotoxicity in rats. Iran. J. Kidney Dis., 6(1): 25-32.

Valle, S. (1986): Special stains in microwave oven. J. Histotechnol., 9: 237-248.

Welch, W. J. (2006): Intrarenal oxygen and hypertension. Cl. Exp. Pharma. Physiol., 33: 1002-1005.

Yu, Y.; Shen, M.; Song, Q., and Xie, J. (2018): Biological activities and pharmaceutical applications of polysaccharide from natural resources. Carbohydrate Polymers, 183(1): 91-101.

Zaghloul, M. S. and Salem, M. A. (2001): Ultrastructure, histochemical and biochemical effect of chronic exposure to different types of electromagnetic radiation on the liver of albino rats. Proc. Zool. Soc. A. R. Egy., 37(2):67-89.

Zhou, R.; Long, H.; Zhang, B. et al. (2019): Salvianolic acid B, an antioxidant derived from Salvia militarize, protects mice against $\gamma$-radiation-induced damage through Nrf2/Bach1. Mol. Med. Reports, 19: 1309-1317. 